\title{
Quality of life in municipal public health managers: a cross-sectional study from Brazil
}

\begin{abstract}
Introduction: The work of the public health manager is very challenging, and its association with risk factors can lead to negative impacts on quality of life.
\end{abstract}

Objective: Identify and evaluate quality of life of public health managers and its association with demographic, socioeconomic factors.

Methods: Data were obtained through filling of three questionnaires, one being the WHOQol-BREF to collect data related to quality of life. Descriptive statistical analysis was performed through frequency calculation. For analytical analysis, the Chi-square test and Fisher's Exact Test were applied.

Results: Most participants reported satisfaction from working as a health manager and $87 \%$ believed their work was recognized. The following variables presented significant association with better quality of life: housing, educational background, health conditions, satisfaction as a manager and recognition. Among the 199 participants, 158 reported to have one or more health changes. Regarding professional daily practice as a manager, more than half of the sample was in towns with up to 20,000 inhabitants and worked more than 8 hours a day.

Conclusion: As a conclusion, health managers of the state of São Paulo present general sufficient quality of life.

Keywords: quality of life, health manager, unified health system, job satisfaction
Volume 6 Issue 2 - 2018

\section{Rosana de Fatima Possobon, Nelo Augusto Poleto, Livia Fernandes Probst, Tatila de Oliveira Lima, Luciane Miranda Guerra, Glaucia Maria Bovi Ambrosano, Karine Laura Cortellazzi}

Department of Community Dentistry, Piracicaba Dental School Unicamp, Brazil

Correspondence: Rosana de Fatima Possobon, Department of Community Dentistry, Piracicaba Dental School, Brazil, Tel 5519 21065363,Email possobon@fop.unicamp.b

Received: February 21, 2018 | Published: April 04, 2018

\section{Introduction}

Quality of life has been a subject of growing interest in Brazil and internationally, both in the field of public health and public policies, which can be observed through production references of knowledge and research. ${ }^{1-5}$ Conceptually, quality of life can be understood as the individuals' perception of their position in life, in the context of culture and value systems in which they live considering their goals, expectations, standards and concerns. ${ }^{6}$

Thus, we notice that quality of life is associated with a multidimensional character and can be divided into four dimensions:Physical: perception of individuals about their physical condition;psychological: individuals' perception about their affective and cognitive condition;--social relationships: perception of individuals about social relationships and social roles adopted in life;environment: the individuals' perception on various aspects related to the environment where they live. ${ }^{7}$

In the second half of the 20th century, with the purpose of improving individuals' working conditions and, consequently, to improve their performance for companies, the quality of life at work movement emerged. ${ }^{8}$ The damage caused to health, resulting from occupational stress, has been producing studies that aim to improve the quality of life of workers through prevention and health promotion, ${ }^{9}$ so that four dimensions that influence quality of life at work ${ }^{10}$ were suggested, which are: 1. Political dimension: represented by the concept of job security. 2. Economic dimension: represented by wage equity. 3. Psychological dimension: represented by the self-fulfillment concept. 4. Sociological dimension: represented by participation of the professional in the whole work process, executing and assuming responsibilities in the team.
The strengthening of the health sector in Brazil created new demands for generic and specialized development of health administration technologies. ${ }^{11}$ Municipal health managers are responsible for a set of functions and procedures, such as: decisions, action planning, financial and administrative management, to manage conflicts generated by employees, institutions and users. ${ }^{12,13}$ We can say the work schedules of these professionals have no simple matters, in addition to existence of a set of facts that can be understood as conflicts. ${ }^{12}$ Frequently, the manager feels pressure to meet expectations, demands and challenges of the Unified Health System (SUS) satisfactorily, which leads to various stressing factors.

We understand that health managers' job is also very challenging, and its association with risk factors may lead to negative impacts on quality of life ${ }^{14}$ and the quality of services offered by the Unified Health System depends on the fact that these professionals understand, want and are engaged in the work project of the institution, in order to be an active and integrated part of it. However, daily life situations in the workplace show that there are obstacles of several kinds that cross relationships, preventing employees from cooperating with the institution for which they work, creating situations that may lead these professionals to act oppositely to the System normative guidelines. ${ }^{14,15}$

Obviously, this creates difficulties for the institution and for patients who depend on it. Therefore, identifying variables that influence appearance of stress and illness in professionals such as workload excess, pressure from patients and civil servants and even from the leadership, dissatisfaction and lack of recognition for their work, is crucial for planning actions that promote appropriate means to preserve the health of these professionals. ${ }^{14,15}$ Furthermore, despite the vast literature about quality of life, there are no studies 
on this subject related to health public managers, which stresses the originality and relevance of this study.

\section{Methods}

\section{Ethical aspects}

This research was approved by a local Research Ethics Committee, under the protocol number 059/2013.

\section{Characterization of the study, development location and sample}

Analytical, cross-sectional and exploratory study with quantitative methodology, based on questionnaires, involving health municipal public managers from the state of Sao Paulo in Brazil. The state of Sao Paulo has 645 municipalities, all of which have a health public manager and among these municipalities, 403 have up to 20,000 inhabitants, 167 have from 20,001 to 100,000 inhabitants, 36 have from 100,001 to 200,000 inhabitants, and 39 have over 200,000 inhabitants. All health public managers of the state of Sao Paulo in activity during the research development were contacted through electronic message (E-mail), whose addresses were provided by the Council of Municipal Health Secretaries of the state of São Paulo "Dr. Sebastiao de Moraes" (COSEMS), and invited to participate in the research. Among the public managers who agreed to participate in the study $(\mathrm{N}=203)$, those who answered incorrectly or incompletely any of the questionnaires used for data collection $(\mathrm{N}=4)$ were excluded.

\section{Instruments used for data collection}

When accepting the invitation to participate in the research, managers got access to a link that referred to the Informed Consent Form and should agree to the terms of this document before beginning to fill out the questionnaires for data collection. All questionnaires described below were answered online. Demographic data: We used a structured questionnaire composed of ten questions about gender, age, marital status, number of children, number of inhabitants of the municipality where they work, another professional activity besides public administration, daily working hours, health problems, job satisfaction degree as a manager and perception about recognition of their work. Socioeconomic data: the second instrument, which investigated information about the socioeconomic characteristics of the manager, was formed by five questions. ${ }^{16}$ Topics covered by this instrument were the following: monthly family income, number of people residing in the same house, educational background, type of residence and occupation. Level of quality of life: We used the short version of the instrument World Health Organization Quality of life (WHOQol-BREF), which allows evaluation of quality of life of adult populations and which was validated for Portuguese language by Fleck et al. ${ }^{17}$ The WHOQol-BREF consists of 26 questions, being 2 general questions and 24 representing facets that form the original instrument and are related to four domains: physical, psychological, environmental and social relationships.

\section{Analyzed variables and data analysis}

The dependent variable investigated was the quality of life level, dichotomized by the median and classified into worse and better, associated with the following independent variables:

a. Gender-Male and Female b. Age group-Dichotomized by the median and presented as: 43 years old or younger and older than 43 years old.

c. Marital status-Single, Married, Divorced or Widowed.

d. Number of children-Dichotomized by the median and presented as: up to two children and three or more children.

e. Number of people in the house-Dichotomized by the median and presented as: up to three people and four or more people.

f. Housing-Own paid/financed residence, Rented/Conceded residence

g. Educational background-Unfinished higher education and completed higher education

h. Occupation-Healthcare occupations and similar, other occupations.

i. Family income-Dichotomized by the median and presented as: lower than or equal to $\mathrm{R} \$ 4,665$, higher than $\mathrm{R} \$ 4,666$.

j. Health conditions-No problem, with one or more problems

k. Number of inhabitants of the municipality-Dichotomized by the median and presented as: up to 20,000 inhabitants and over 20,000 inhabitants.

1. Works in another activity-Yes, No.

$\mathrm{m}$. Time as public manager-Dichotomized by the median and presented as: up to a year, over a year.

n. Working hours-up to 8 hours per day, Over 8 hours per day.

o. Satisfaction with public manager position-Completely satisfied, partially satisfied, Unsatisfied.

p. Feels recognized for their work-Totally, Partially, No.

Data obtained were automatically turned into spreadsheets on Microsoft Excel and analyses were processed using the Stata software version 12.0. Descriptive statistical analysis was performed through frequency calculation. For statistical analysis, the Chi-square test and Fisher's Exact Test were applied.

\section{Results}

Response rate was $31.5 \%$, that is, out of the 645 invited managers, 203 agreed to participate. In the final sample (199), after exclusion of four participants due to incomplete or incorrect filling of some data collection instruments, there was a higher representation of managers from towns with up to 20,000 inhabitants (59.8\%). However, there was a bigger response rate of managers from towns with a population between 20,000 and $100,000(35.9 \%)$.

Table 1 presents information about socioeconomic and demographic data of participants. Most participants were females $(61.3 \%)$. More than half of the samples $(52.3 \%)$ were in the age group between 35 and 50, being 43 the average age. Most of them were married (65.3\%) and had children (74.9\%). Income of $60.8 \%$ of participants was higher than R\$ 4,666 and $81.4 \%$ lived in an own residence, with up to 4 people $(92.5 \%)$. The majority $(86.4 \%)$ reported completed higher education as educational background and $66.3 \%$ were healthcare professionals. 
Table I Socioeconomic and demographic characterization of the sample of health public administrators from the state of Sao Paulo. Year $2013(n=199)$

\begin{tabular}{ll}
\hline \multirow{2}{*}{ Analyzed variables } & \multicolumn{2}{c}{ Sample } \\
\cline { 2 - 2 } & N $\%$ \\
\hline
\end{tabular}

\section{Gender}

Male

$\begin{array}{ll}77 & 38.7\end{array}$

Female

$122 \quad 61.3$

\section{Age group}

Below 35 years old

$46 \quad 23$.

From 35 to 50 years old

$104 \quad 52.3$

Over 50 years old

$49 \quad 24.6$

\section{Marital status}

Married

$130 \quad 65.3$

Single

Divorced

Widowed

\section{Number of children}

None

One

Two

Three

Four or more

84

\section{Educational background}

Unfinished Higher Education

Completed Higher Education

$26 \quad 13.6$

$173 \quad 86.4$

\section{Occupation}

Healthcare occupations and similar

Other occupations

\section{Health conditions}

No problem

With one or more problems

\section{Household income}

From $R \$ 1,245$ to $R \$ 3,110$

From $\mathrm{R} \$ 3, \mathrm{II}$ I to $\mathrm{R} \$ 4,665$

From $R \$ 4,666$ to $R \$ 6,220$

Higher than $R \$ 6,221$

Number of people in the house

Up to two people
Table Continued

\begin{tabular}{|c|c|c|}
\hline \multirow{2}{*}{ Analyzed variables } & \multicolumn{2}{|c|}{ Sample } \\
\hline & $\mathbf{N}$ & $\%$ \\
\hline Four people & 62 & 31.2 \\
\hline Five people & 9 & 4.5 \\
\hline Six people & 6 & 3 \\
\hline \multicolumn{3}{|l|}{ Type of residence } \\
\hline Own paid residence & 120 & 60.3 \\
\hline Own financed residence & 42 & 21.1 \\
\hline Residence conceded by parents or relatives & 10 & 5 \\
\hline Rented/Conceded residence & 27 & 13.6 \\
\hline \multicolumn{3}{|l|}{ Works in another activity } \\
\hline Yes & 69 & 34.7 \\
\hline No & 130 & 65.3 \\
\hline
\end{tabular}

Regarding professional daily practice as managers, more than half $(59.8 \%)$ were in towns with up to 20,000 inhabitants and were working as managers for less than a year (53.3\%), and worked more than 8 hours a day. The majority (97\%) reported feeling partially or completely satisfied with working as a health public manager and $87 \%$ thought their work was partially or fully recognized (Table 2).

Table 2 Characterization of the sample of health public administrator's work from the state of Sao

\begin{tabular}{|c|c|c|}
\hline \multirow{2}{*}{ Analyzed variables } & \multicolumn{2}{|c|}{ Sample } \\
\hline & $\mathbf{N}$ & $\%$ \\
\hline \multicolumn{3}{|c|}{ Number of inhabitants of the municipality } \\
\hline Up to 20,000 & 119 & 59.8 \\
\hline From 20,001 to 100,000 & 60 & 30.2 \\
\hline From 100,000 to 200,000 & 10 & 5 \\
\hline Over 200,000 & 10 & 5 \\
\hline \multicolumn{3}{|l|}{ Time as a public administrator } \\
\hline Less than a year & 106 & 53.3 \\
\hline From 2 to 4 years & 34 & 17.1 \\
\hline From 5 to 10 years & 36 & 18.1 \\
\hline From II to I5 years & 14 & 7 \\
\hline From 16 to 20 years & 6 & 3 \\
\hline Over 20 years & 3 & 1.5 \\
\hline \multicolumn{3}{|l|}{ Working hours } \\
\hline Up to 8 hours a day & 59 & 29.7 \\
\hline From over 8 to 10 hours a day & 61 & 30.6 \\
\hline From over 10 to 12 hours a day & 34 & 17.1 \\
\hline
\end{tabular}


Table Continued

\begin{tabular}{ll}
\hline \multirow{2}{*}{ Analyzed variables } & \multicolumn{2}{c}{ Sample } \\
\cline { 2 - 2 } & N \% \\
\hline
\end{tabular}

\section{Satisfaction}

$\begin{array}{lll}\text { Completely satisfied } & 43 & 21.6 \\ \text { Partially satisfied } & 150 & 75.4 \\ \text { Dissatisfied } & 6 & 3 \\ \text { Recognition } & & \\ \text { Totally } & 28 & 14.1 \\ \text { Partially } & 145 & 72.9 \\ \text { No } & 26 & 13\end{array}$

In addition, the majority of the sample (79.9\%) reported they had one or more health changes (Table 3). Among participants who reported a change in health $(\mathrm{n}=158)$, one-third claimed to feel stressed or anxious, and a prevalence higher than $14 \%$ for hypertension and back problems was found (Table 4). Another important fact is that $55.3 \%$ out of the total sample $(\mathrm{n}=199)$, i.e., 110 public managers reported stress/anxiety. When considering only the sample of public managers who had health issues $(n=158)$, this index rises to $69.6 \%$ (110 out of 158). There were three pregnant women among the managers, and two of them reported to feel stress and anxiety. It should be noted that none of the public managers gave information about use of alcohol and drugs.

Table 3 Health conditions presented by health public administrators from the state of São Paulo Year 2013 ( $n=\mid 58)$

\begin{tabular}{|c|c|c|}
\hline Health condition & $\mathbf{N}$ & $\%$ \\
\hline Stress/anxiety & 110 & 34.6 \\
\hline Depression & 14 & 4.4 \\
\hline Hypertension & 49 & 15.4 \\
\hline Cardiopathy & 3 & I \\
\hline Diabetes & 14 & 4.4 \\
\hline Spine problems & 46 & 14.5 \\
\hline Arthritis or rheumatism & 10 & 3.1 \\
\hline Ulcers or gastritis & 29 & 9.1 \\
\hline Emphysema or bronchitis & 7 & 2.2 \\
\hline Skin disease & 12 & 3.8 \\
\hline Cataract or visual loss & 9 & 2.8 \\
\hline Voice problems & 8 & 2.5 \\
\hline Hearing loss & 5 & 1.6 \\
\hline Pregnant women & 2 & 0.6 \\
\hline Problems with alcohol or drugs & 0 & 0 \\
\hline Total & 318 & 100 \\
\hline
\end{tabular}

Table 4 Factors associated with quality of life of health public administrators from the state of São Paulo. Year $2013(n=199)$

$\begin{array}{lr} & \begin{array}{r}\text { Quality of life } \\ \text { Worse }\end{array} \\ \leq 65.5 & \text { Better } \\ & >65.5\end{array}$

Variables

$\begin{array}{ll}(n=100 ; & (n=99 ; \\ 50.2 \%) & 49.8 \%)\end{array}$

$\begin{array}{lllll}\mathbf{N} & \% & \mathbf{N} & \% & \mathbf{P} \\ & & \text { value }\end{array}$

Gender

0.097

$\begin{array}{lllll}\text { Male } & 33 & 42.9 & 44 & 57.1 \\ \text { Female } & 67 & 54.9 & 55 & 45.1\end{array}$

Age group

0.523

$\begin{array}{lllll}\leq 43 & 48 & 48 & 52 & 52 \\ >43 & 52 & 52.5 & 47 & 47.5\end{array}$

Marital status

0.129

$\begin{array}{lcccc}\text { Single } & 63 & 48.5 & 67 & 51.5 \\ \text { Married } & 17 & 43.6 & 22 & 56.4 \\ \text { Divorced or widowed } & 20 & 66.7 & 10 & 33.3\end{array}$

Number of children

0.223

$\begin{array}{lcccc}\text { Up to two children } & 88 & 52.1 & 81 & 47.9 \\ \begin{array}{l}\text { Three or more } \\ \text { children }\end{array} & 12 & 40 & 18 & 60\end{array}$

Number of people in the house

0.622

$\begin{array}{lllll}\text { Up to three people } & 63 & 51.6 & 59 & 48.4 \\ \text { Four or more people } & 37 & 48 & 40 & 52\end{array}$

Type of residence

0.02

$\begin{array}{lllll}\text { Own paid/financed } & 75 & 46.3 & 87 & 53.7\end{array}$

$\begin{array}{lllll}\text { residence } & 75 & 46.3 & 87 & 53.7 \\ \text { Rented/Conceded } & & & & \\ \text { residence } & 25 & 67.6 & 12 & 32.4\end{array}$

$\begin{array}{lllll}\text { residence } & 25 & 67.6 & 12 & 32.4\end{array}$

Educational background:

0.021

Unfinished Higher

Education

$\begin{array}{llll}8 & 29.6 & 19 & 70.4 \\ 92 & 53.5 & 80 & 46.5\end{array}$

$\begin{array}{lllll}\text { Higher education } & 92 & 53.5 & 80 & 46.5\end{array}$ 
Table Continued

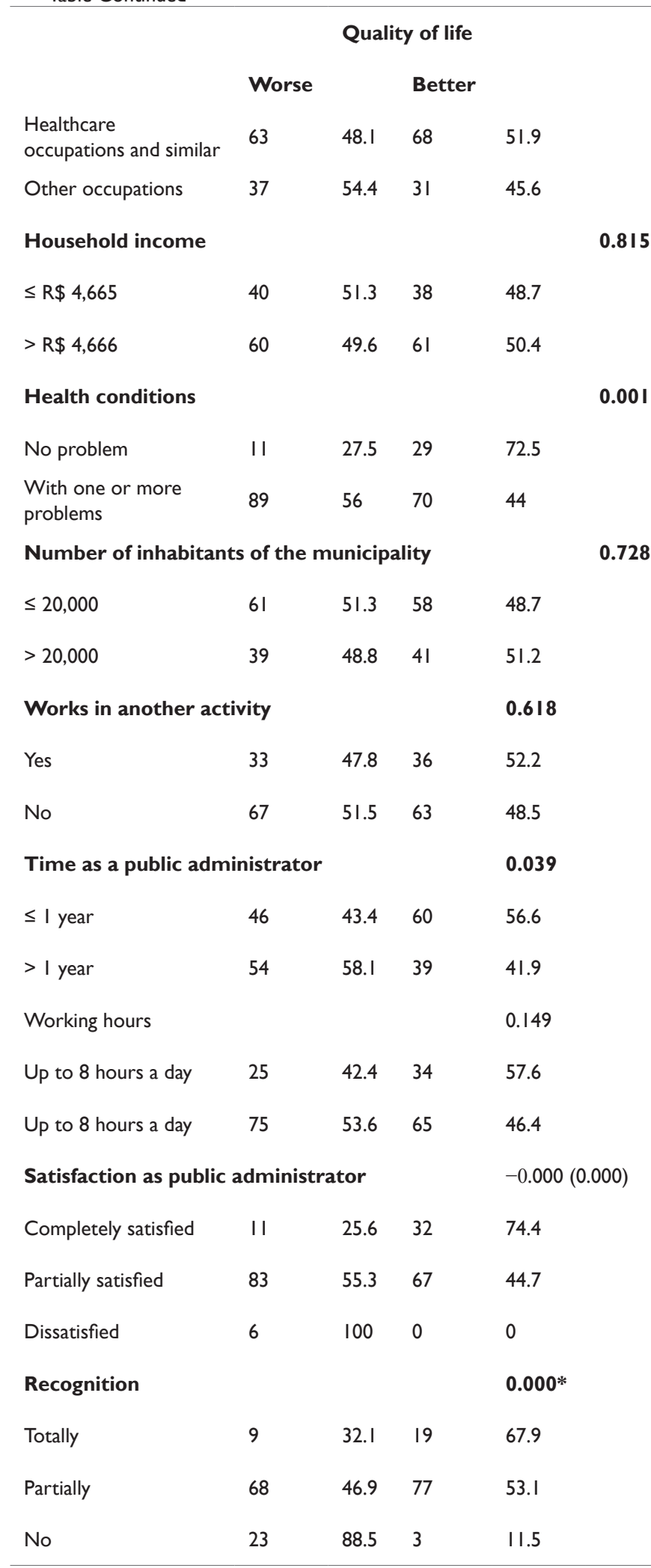

Statistical analysis: Chi-square; except $*$ where Fisher's Exact Test was carried out.

Regarding general quality of life, more than half (50.2\%) perceived their own quality of life as bad. Associations between quality of life level and the several independent variables were investigated, as presented on (Table 4), and the best quality of life was observed among the public managers who had their own residence $(p=0.02)$, had at least unfinished higher education level $(p=0.021)$, were at the administration for a year or less $(p=0.039)$, felt satisfied as public managers $(p=0.00)$ and perceived recognition for their performance $(p=0.00)$.

Observing data on quality of life domains, presented on (Table 5), we notice that the physical domain presented the highest average score, followed by the social relationships and psychological domains. The domain that presented the lowest average score was the relative to the environment. Regarding the median, we notice that the psychological and the environment domains presented equal values. The domain related to the environment also presented the lowest median.

Table 5 Median, mean score, standard deviation, minimum and maximum values of the WHOQOL-BREF domains and General Quality of Life (GQoL) of health public administrators from the state of Sso Paulo.Year $2013(n=199)$

\begin{tabular}{llllll}
\hline $\begin{array}{l}\text { Domains } \\
\text { GQoL }\end{array}$ & Media & $\begin{array}{l}\text { Mean } \\
\mathbf{n}\end{array}$ & $\begin{array}{l}\text { Standard } \\
\text { Score }\end{array}$ & $\begin{array}{l}\text { Mini- } \\
\text { deviation }\end{array}$ & $\begin{array}{l}\text { Maxi- } \\
\text { vum } \\
\text { value }\end{array}$ \\
\hline Physical & 71.4 & 68.7 & 13.4 & 25 & 100 \\
Psychological & 66.7 & 64.2 & 14.3 & 20.8 & 100 \\
Social & 66.7 & 65.2 & 17 & 25 & 100 \\
Relationships & & & & & \\
Environment & 62.5 & 60.4 & 12.7 & 15.6 & 96.9 \\
GQoL & 65.3 & 64.6 & 11.8 & 33.7 & 92.5 \\
\hline
\end{tabular}

\section{Discussion}

This study adds important information concerning quality of life of municipal health public managers. Since there is no other studies related specifically to these professionals, the data obtained in this research can be compared to equivalent studies with other professionals, such as nurses, doctors and university professors. ${ }^{2-5}$ Therefore, this is an original study.

Many social aspects linked to work in general contribute to raise morbidity load in workers, among which stands out the following: increasing competitiveness, intensity of human relationships in the work scope, increase of psychological violence in workplaces and pressure that comes from economic features of globalization. ${ }^{18}$ In the same way as other healthcare professionals, public managers are also exposed to factors that may affect their health and compromise their work performance. Therefore, looking for subsidies to understand and control risk variables to professional exhaustion allows further improvement of care offered to health public managers and SUS patients as well. ${ }^{19}$

Regarding general characteristics of the sample, this study found that over half perceived their quality of life as bad, similar to the findings of Rodriguez et al ${ }^{20}$ which evaluated primary care physicians and found, in addition to the perception of low quality of life, reports of symptoms, such as lack of time, oppressive feeling and negative views at work with pessimistic ideas about the future.

Municipal health public managers mostly work in the combat line, which requires flexibility and ability to manage conflicts, having on one side patients and their health demands and, on the other, their 
superiors (in this case, mayors), with their budget limitations and administrative strategies that may be not consonant with perspectives of managers. This work dynamic may have contributed to the fact that one third of the sample reported stress or anxiety as a health problem. Stress affects each individual in a unique way and causes different responses, being some work environments propitious to its high-level development, especially if a professional does not have a set of appropriate confrontation strategies, which causes an imbalance between work demands and execution capabilities of these demands. ${ }^{21}$

An important variable when investigating risk factors to quality of life concerns daily working hours. In a study that evaluated quality of life in primary healthcare professionals in Spain, Rodriguez et al. ${ }^{20}$ found low perceived quality of life so that working hours (from medium to high) contributed significantly to this perception.Gueiros ${ }^{22}$ found a similar situation among teachers and found that the higher the working hours, the higher stress levels will be. Studying specifically working stress, other researchers have shown that work overload may increase chances of developing stress. ${ }^{23,24}$

At first, these results seem to conflict with the findings of this study, in which more than two-thirds of the sample claimed to work more than eight hours a day, nevertheless, this workload was not significant in perception of quality of life. However, it must be considered that over half respondents were in the administrating position for less than a year, that is, it is possible that the short time in the public administration had not allowed them to feel the heaviness of working hours yet. Public managers still beginning their activities formed much of the sample since data collection was held months after the new mayors took office, which were elected in the municipal election closer to this research. It is known that, by taking office of a municipality, mayors often choose new health managers, as it is a position of trust of governments.

This fact may have influenced general levels of quality of life, once among these new managers; there was a better quality of life. We infer that time devoted to administration could result in worse quality of life due to accumulation of responsibilities and the frequent need to be faced with conflicting situations. In addition, new work challenges tend to be stimulating for some professionals, which may explain better quality of life among these public managers in early activity. ${ }^{25}$

A public manager collaborates directly with development and management of strategies and actions and, this participation along with the exercise of their originality and ability to overcome obstacles, can make work more pleasant. ${ }^{26}$ The bigger the commitment and autonomy in the development of activities, the higher the professional achievement and satisfaction levels. ${ }^{27}$ These findings corroborate the results found in this study, in which a tiny portion of the sample demonstrated dissatisfaction with work. The highest degree of satisfaction reported was significantly associated with better quality of life. Teles et al. ${ }^{28}$ also reported that, when unsatisfied with their jobs, workers present a higher probability to assess their quality of life negatively.

However, the job is not always source of professional fulfillment and can often generate dissatisfaction and exhaustion problems. ${ }^{29}$ Enjoying what you do is one of the main reasons of job satisfaction pointed out by primary healthcare professionals. Despite that, satisfaction degree can be limited by difficulties found in the work routine, such as inability to solve patients' problems, which can lead to frustration and dissatisfaction. ${ }^{30}$
The majority of respondents in this study reported having a health change, which was significantly associated with a worse quality of life. Similarly, the study by Teles et al. ${ }^{28}$ with 760 primary healthcare professionals, identified that those who perceived their own health as compromised, also evaluated negatively their quality of life, and there was also a higher prevalence of poor quality of life among workers over committed to work. It can be inferred that work organization can influence public managers' health, whose commitment degree can become excessive, especially if there is search for approval and recognition as underlying motivation, making self-control on daily tasks difficult, such as taking care of their own health. This situation can lead to health issues that go beyond stress and psychological damage and also involve cardiovascular problems. ${ }^{28}$

Thus, in general, we can say that municipal health public managers struggle directly with dilemmas that require agility and decisionmaking ability, both for basic needs and for increasing healthcare complexity that people demand. Therefore, accumulation of functions by these professionals and pressure to meet demand and improve quality of services offered, can generate a work overload, leading to health changes, dissatisfaction and attitudes considered inappropriate in a healthcare assistance context, such as difficulties in working in teams, respecting knowledge of other professionals and working in an empathetic way with patients, resulting in poor quality of services offered. Through practices of prevention and health promotion, aimed at improving quality of life in the workplace, it is possible to control situations that interfere with work quality and increase professional interest in participating in the work process, in the execution of actions and in their responsibility for the team. ${ }^{10}$

In 2015, Mialhe ${ }^{31}$ explained that, after nearly three decades since Ottawa's Charter publication, managers, professionals and government still use the expression "Health Promotion" the way it is more convenient for them. Thus, there is a limited definition which, according to Tanhill, ${ }^{32}$ is about activities that help people improve their unhealthy or risk behaviors, usually through traditional educational activities that disregard macro, determining and conditioning aspects of behaviors. However, Mialhe ${ }^{31}$ also points out a new perspective, which is ecological and wide, based on educational activities aimed at empowerment of individuals to deal with determinants of their own health as legal environmental standards. In this sense, the aim is making healthy choices the easiest ones.

In this study, recognition for their roles as managers influenced quality of life. A similar result was found by Munoz-Seco et al. ${ }^{33}$ who evaluated quality of life in primary healthcare professionals and verified that general organizational environment influences general quality of life at work, especially in the sense of motivating workers and make them notice management support. These authors reported that teams that made a better evaluation of recognition received were those that presented a higher quality of life, higher motivation and lower perception of demands. ${ }^{33}$

Better quality of life among public managers who had their own residences was observed, nevertheless, there was no significant relation between family income and quality of life. These results differ from those presented by Kim \& Park ${ }^{4}$ who, when assessing impact of socioeconomic status and social class on quality of life of people in general, found that individuals with low family income and low class had a higher probability of presenting low quality of life.

Educational level may be positively associated with someone's 
quality of life. ${ }^{4}$ However, in this study; respondents with unfinished higher education were the ones who presented a better quality of life, although most participants informed completed higher education as educational background. The findings of this study can be understood by analyzing the studies by Benevides-Pereira, ${ }^{27}$ and Carlotto $^{34}$ which results pointed out that the higher the educational level, the higher the stress levels and the sense of responsibility, which may influence quality of life. Professionals with an excessive involvement degree with work tend to exaggerate in their effort, which leads to excessive tension for underestimating the challenge and increase of hours dedicated to labor issues' resolutions, leading consequently to fatigue..$^{28}$

From the results of this study, conduction of qualitative research may be suggested to explore and evaluate some health public managers' feelings related to the work situation. In addition, replication of data collection on the same sample among public managers who are still active, after a few years in the administration, may enlighten some discussions concerning working time, satisfaction degree and perceived recognition, and association of such variables with quality of life. Moreover, deeper studies related to quality of life among the municipal health public managers from other regions of the country would be relevant as well, taking into consideration characteristics of the administration model of each region as a variable potentially associated with quality of life.

Therefore, this study can contribute significantly to the organization of public health service, whereas a low quality of life at work combined with recurrent health problems may lead to absenteeism and/or low productivity, which consequently would take greater onus to SUS, given the importance and specificity of the municipal health public manager function.

\section{Conclusion}

Based on the results, we can conclude that health public managers from the state of Sao Paulo, in general present a bad perception about their quality of life. This study demonstrated that perceived satisfaction, as well as recognition for their work, reflects significantly on the perception of quality of life.

\section{Acknowledgements}

The authors tanks to all health public managers from the state of Sao Paulo that contributed with this survey.

\section{Conflict of interest}

The authors declared that there is no conflict of interest.

\section{References}

1. Seidl EMF, Zannon CML. Qualidade de vida e saude: aspectos conceituais e metodológicos. Cad Saude Publica. Rio de Janeiro. ;20(2):580-88.

2. Farias SNP, Zeitoune RCG. A Qualidade de Vida no Trabalho de Enfermagem. Esc Anna Nery. 11(3):487-493.

3. Oliveira Filho A, Netto Oliveira ER, Oliveira AAB. Qualidade de vida e fatores de risco de professores universitários. Rev educ fis. 2012;23(1):57-67.

4. Kim JH, Park EC. Impact of socioeconomic status and subjective social class on overall and health-related quality of life. BMC Public Health 2015;15:783.
5. Liu C, Wang S, Shen X, et al. The association between organizational behavior factors and health-related quality of life among college teachers: a cross-sectional study. Health and quality of life outcomes. 2015;13:85

6. The Whoqol Group. The development of the World Health Organization quality of life assessment instrument (the WHOQOL). In: Orley J, Kuyken W,(editors). Quality of life assessment: international perspectives. Heigelberg: Springer Verlag; 1994. p. 41-60.

7. Minayo MCS, Hartz ZMA, Buss PM. Qualidade de vida e saude: um debate necessario. Cienc Saude Colet. 2000;5(1):7-18.

8. Fernandes SRP. Transformacoes no mundo do trabalho e a saude psiquica: aotica do estresse ocupacional. $O \& S$. 1999;6(16):67-75.

9. Camargo DA, Oliveira JI. Riscos ocupacionais: repercussões psicossociais. Apud: Guimarães, LAM, Grubits, S (Og.) Série saúde mental e trabalho, São Paulo: Casa do Psicólogo; 2004. p. 157-181.

10. Westley WA. Problems and Solutions in the Quality of Working Life. Human Relations. 1979;32(2):113-123.

11. Mehry EE. O ato de governar as tensoes constitutivas do agir em saude como desafio permanente de algumas estrategias gerenciais. Cienc Saude Colet. 1999;4(2):305-314.

12. Cecilio LCO. E possivel trabalhar o conflito como materia-prima da gestao em saude?. Cad Saude Publica. 2005;21(2):508-516.

13. Ministerio da Saude. Doencas relacionadas ao trabalho. Manual de procedimentos para os servicos de saude. Brasilia: 2001.

14. Moretto MLT, Jaen AC, Benute GRG, et al. "Cuidando de quem cuida": assistência psicológica ao trabalhador da saude. Psicologia Hospitalar. 2013;11(1):52-65.

15. Elias MA, Navarro VL. A relacao entre o trabalho, a saude e as condicoes de vida: negatividade e positividade no trabalho das profissionais de enfermagem de um hospital escola. Rev Lat Am Enfermagem. 2006;14(4):517-525.

16. Meneghim MC, Kozlowski FC, Pereira AC, et al. Classificacao socioeconomica e sua discussao em relacao a prevalencia de carie e fluorose dentaria. Cien Saude Colet. 2007;12(2):523-529.

17. Fleck MPA, Louzada S, Xavier M, et al. Aplicacao da versão em portugues do instrumento abreviado de avaliacao da qualidade de vida “WHOQOL-bref”. Rev Saude Publica. 2000;34(2):178-183.

18. Barbosa RMDSA, Aquino Guimaraes T. Sindrome de Burnout: Relacoes com Comprometimento afetivo entre gestores de organizacao estatal. Revista de Administracao Mackenzie. 2008;6(1):157-179.

19. Martins LF, Laport TJ, Menezes VP, et al. Esgotamento entre profissionais da Atencao Primaria a Saude. Cien Saude Colet. 2014;19(12):4939-4750.

20. Rodriguez FJ, Ramos MB, Perez SI, et al. Relacion de la calidad de vida profesional y el burnout en medicos de atencion primaria. Atencion primaria. 2005;36(8):442-447.

21. Alpi VS, Quiceno JM. Burnout: "Sindrome de Quemarse en el Trabajo (SQT)". Act Colom Psicol. 2007;10(2):117-125.

22. Gueiros, MG. Estresse ocupacional de professores: seus indicadores, suas fontes e as estratégias utilizadas para combatê-1o - Um estudo de caso na Universidade Federal de Pernambuco. [dissercatao]. Recife: Universidade Federal de Pernambuco; 2005.

23. Lautert L. A sobrecarga de trabalho na percepcao de enfermeiras que trabalham em hospital. Rev Gaucha Enferm. 1999;20(2):50-64.

24. Lacaz FAC. Qualidade de vida no trabalho e saude doenca. Cien Saude Colet. 2000;5(1):151-161. 
25. Costa LST, Gil Monte PR, Possobon RF, et al. Prevalencia da Sindrome de Burnout em uma amostra de professores universitarios brasileiros. Psicol Reflex.Crit. 2013;26(4):636-642.

26. Dejours C. A loucura do trabalho: estudo da psicopatologia do trabalho. Sao Paulo: Obore; 1994.

27. Benevides Pereira AMT. Organizador. Burnout: quando o trabalho ameaca o bem estar do trabalhador. Sao Paulo: Casa do psicologo; 2002.

28. Teles MAB, Barbosa MR, Vargas AMD, et al. Psychosocial work conditions and quality of life among primary health care employees: a cross sectional study. Health Qual Life Outcomes. 2014;12 (1):1-12.

29. Lima RAS, Souza AI, Galindo RH, et al. Vulnerabilidade ao burnout entre medicos de hospital publico do Recife. Cien Saude Colet. 2013;18(4):1051-1058

30. Bracarense CF, Costa NS, Duarte JMG, et al. Qualidade de vida no trabalho: discurso dos profissionais da Estrategia Saude da Familia. Esc Anna Nery. 2015;19(4):542-548.
31. Mialhe F. Promocao da Saude e o Ambiente de Trabalho Saudavel. In: Pereira AC, Guerra LM, Cavalvante DFB, Meneghim MC. (orgs) Gestao Publica em Saude: Fundamentos e Praticas. Ed. Livronovo. Aguas de Sao Pedro, 2015.

32. Tannahill A. What is health promotion? Health Educ J. 1985;44(4):167-168.

33. Munoz Seco E, Coll Benejam JM, Torrent Quetglas M. Influencia del clima laboral en la satisfaccion de los profesionales sanitarios. Atencion primaria. 2006;37(4):209-214.

34. Carlotto MS, Palazzo LS. Sindrome de burnout e fatores associados: um estudo epidemiologico com professores. Cad Saude Publica, Rio de Janeiro. 2006;22(5):1017-1026. 